\title{
The Diagnostic Value of Irisin and Visfatin in Experimental Testicular Torsion
}

\section{Deneysel Testis Torsiyonunda Irisin ve Visfatin'in Tanısal Değeri}

\author{
Fatma Saraç, Selman Yeniocak*, Sevgi Büyükbeşe Sarsu** , Esma Yücetaş***, \\ Vakur Olgaç****, Mehmet Toptaş*****, Macit Koldaş*** \\ University of Health Sciences, Haseki Training and Research Hospital, Clinic of Pediatric Surgery, İstanbul, Turkey \\ *University of Health Sciences, Haseki Training and Research Hospital, Clinic of Emergency Medicine, İstanbul, Turkey \\ **Cengiz Gökçek Obstetrics and Pediatrics Hospital, Clinic of Pediatric Surgery, Gaziantep, Turkey \\ ***University of Health Sciences, Haseki Training and Research Hospital, Clinic of Biochemistry, Istanbul, Turkey \\ $* * * *$ istanbul University, Institute of Oncology, Clinic of Pathology, istanbul, Turkey \\ $* * * * *$ University of Health Sciences, Haseki Training and Research Hospital, Clinic of Anesthesia and Reanimation, Istanbul, Turkey
}

Abstract

\begin{abstract}
Aim: Testicular torsion (TT) is one of the most important causes of acute scrotum in children and young men. Very scarce number of serum laboratory parameters might be used in the early diagnosis of patients with TT. We planned this study in consideration of the possible significance of the changes in serum irisin and visfatin levels in the diagnosis of TT.
\end{abstract}

Methods: We used 28 rats in four groups. In the control group, blood samples and specimens of testicular tissue were collected at $2^{\text {nd }}$ and $4^{\text {th }}$ hours after torsion. In the torsion groups, the left testis was twisted, and blood samples and specimens of the testicular tissue were collected at the $2^{\text {nd }}$ and $4^{\text {th }}$ hours for analysis.

Results: There was no statistically significant difference in mean irisin and visfatin levels at the $2^{\text {nd }}$ and $4^{\text {th }}$ hours between rats with $T$ and controls. There was no statistically difference between mean irisin and vistatin levels at the $2^{\text {nd }}$ hour and at the $4^{\text {th }}$ hour in torsion and control groups.

Conclusion: In our experimental $\Pi$ method, we could not find a statistically significant difference between serum levels of irisin and visfatin. We assume that further studies are needed on this issue.

Keywords: Testicular torsion, experimental, irisin, visfatin

\section{Öz}

Amaç: Testis torsiyonu (TT) çocuklar ve genç erkeklerdeki akut skrotumun en önemli nedenlerinden biridir. $\mathrm{TT}^{\prime} l i$ hastalarda erken tanıda kullanılabilecek serum laboratuvar parametreleri oldukça sınırıdır. Biz de bu çalışmamızı, TT tanısında irisin ve visfatin'in serum düzeylerindeki değişimin anlamlı olabileceğini düşünerek planladık.

Yöntemler: Çalışmamızda dört grupta 28 sıçan kullanıldı. Kontrol gruplarında gubernakulum ortaya konduktan sonra 2. ve 4. saatlerde kan ve testis dokuları alındı. Torsiyon gruplarında ise sol testise torsiyon uygulandıktan sonra 2. ve 4. saatlerde kan ve testis dokuları inceleme için alındı.

Bulgular: TT olan ratlarda 2. ve 4. saat irisin ve visfatin değerlerinin ortalamalarında kontrol grubuna göre anlamlı fark saptanmadı. Torsiyon grubu ve kontrol gruplarının 4. saatteki irisin ve visfatin ortalamaları ile 2. saat ortalamaları arasında da istatistiksel olarak anlamlı fark saptanmadı.

Sonuç: Oluşturduğumuz deneysel TT modelinde, irisin ve visfatinin serum düzeylerinde istatistiksel olarak anlamlı fark bulamadık. Bu konuda ek çalışmalara intiyaç olduğunu düşünmekteyiz.

Anahtar Sözcükler: Testis torsiyonu, deneysel, irisin, visfatin

\section{Introduction}

Testicular torsion (TT) or torsion of the spermatic cord is one of the main causes of acute scrotum especially in children and young men. TT results in cessation of the blood supply to the testis and the surrounding structures. Although it is seen at any age, even during labour, it most frequently peaks during puberty and within the first year
Address for Correspondence/Yazışma Adresi: Fatma Saraç

University of Health Sciences, Haseki Training and Research Hospital, Clinic of Pediatric Surgery, İstanbul, Turkey E-mail: fsarac75@gmail.com ORCID ID: orcid.org/0000-0003-0894-7787

Received/Geliş Tarihi: 5 April 2017 Accepted/Kabul Tarihi: 12 April 2017
'Copyright 2017 by The Medical Bulletin of University of Health Sciences Haseki Training and Research Hospital
The Medical Bulletin of Haseki published by Galenos Yayınevi.

${ }^{\circledR}$ Telif Hakkı 2017 Sağlık Bilimleri Üniversitesi Haseki Eğitim ve Araştırma Hastanesi Haseki Tıp Bülteni, Galenos Yayınevi tarafindan basılmışıı. 
of life. Its incidence in men younger than 25 years of age is $1 / 4000(1-6)$.

Time is very important in TT. If intervened within the first six hours after onset of symptoms, the testis may recover. Viability of the testis decreases dramatically after 12 hours. Since wasting time for differential diagnosis will lead to loss of the testis, diagnostic process should be done as soon as possible $(1,3,5,6)$. It may be sometimes not possible to utilize some diagnostic methods such as Doppler ultrasonography (US) and scintigraphy in patients admitted to emergency departments. Very limited number of specific and sensitive serum parameters can be used in the differential diagnosis of TT. Therefore, novel biomarkers are needed which may be used in the differential diagnosis of gray zone TT patients so as to aid in the establishment of definitive diagnosis.

Irisin is accepted as an exercise-induced hormone derived from skeletal muscles. It is also produced in many tissues including adipose tissue, liver, heart and salivary gland (7-12). Irisin is a component of fibronectin type 3-domain containing 5 (FNDC5) protein. FNDC5 induces secretion of irisin from muscle cells. As a precursor of irisin, secretion of FNDC5 mRNA in the seminal vesicle, penis and testes has been also reported $(13,14)$.

Visfatin is a polypeptide consisting of 491 amino acids and its gene is located on the long arm of the chromosome 7 (15). Since it stimulates $\beta$-cell maturation and inhibits apoptosis, it is accepted as a cytokine. Besides, as demonstrated in many studies, it enables activation of leukocytes, and increases production of proinflammatory cytokines (16).

We planned this experimental study considering that changes in serum levels of irisin and visfatin might have a significant role in the diagnosis of TT.

\section{Methods}

Our experimental study was performed in the Experimental Animal Studies Research Laboratory at Bezmialem Foundation University in Istanbul, Turkey (number of ethics approval: 2015/132). Financial support for the study was received from the Advisory and Monitoring Commission for Dissertations and Academic Studies of Haseki Training and Research Hospital. A total of 28 prepubertal 26-30 day-old Wistar-Hannover strain rats each weighing 75-125 g were used in the study. During the experiment, all animals used in the study were followed up under stable ambient conditions and fed with tap water and standard rat pellets.

The rats were anesthetized with $70 \mathrm{mg} / \mathrm{kg}$ ketamine (Ketalar, Pfizer Pharmaceutical Co, Istanbul, Turkey) and 10 mg/kg xylazine (Rompun, Bayer Pharmaceutical Co,
İstanbul, Turkey) and the surgical field was cleansed with povidone-iodine solution and the layers were passed through a transverse incision. Control groups did not undergo any procedure. The left testes of the rats in the torsion groups were rotated around their axes for $720^{\circ}$. Then, the testes were fixed to the scrotum with sutures passing through the tunica albuginea, and placed in the scrotum before closing the layers per primum.

Group 1 (1. Control group): Through scrotal incision, the gubernaculum was explored and two hours later, blood samples and testicular specimens were obtained.

Group 2 (2. Control group): Four hours after exploration of the gubernaculum, blood samples and testicular specimens were obtained.

Group 3 (1. Torsion group): Left testes were rotated to induce ischemia, then, blood samples, and testicular specimens were obtained two hours after induction of ischemia.

Group 4 (2. Torsion group): Blood samples, and testicular specimens were obtained four hours after torsion

At the end of the study, intracardiac blood samples were obtained and bilateral orchiectomy was performed to provide specimens for histopathological analysis. Afterwards, the animals were sacrificed.

Histopathological analyses were performed in the Pathology Department of the Oncology Institute at istanbul University, İstanbul Faculty of Medicine and biochemical analyses were carried out in the division of Clinical Chemistry at Haseki Training and Research Hospital.

\section{Biochemical Analyses}

Serum irisin and visfatin levels of the rats were measured using Rat irisin ELISA kit (Eastbiopharm, Hangzhou-China) and Rat visfatin ELISA kit (Eastbiopharm, Hangzhou-China), respectively.

\section{Histopathological Analyses}

Testicular tissues were fixed in 10\% formaldehyde solution and embedded in paraffin blocks after serial analyses were performed. Four micron-thick standard sections were stained with hematoxylin-eosin. Then, the prepared slides were examined under light microscope and evaluated according to the classification proposed by Cosentino et al. (17).

Stage 1 - Normal testicular tissue.

Stage 2 - Somewhat regular germ cells, and irregular seminiferous tubuli.

Stage 3 - Irregular germ cells, shrinked picnotic nuclei and seminiferous tubuli with irregular contours.

Stage 4 - Seminiferous tubuli filled with irregular germ cells with coagulation necrosis. 


\section{Statistical Analysis}

For statistical analysis, SPSS 15.0 for Windows was used. In descriptive statistics, categorical variables were expressed as numbers and percentages, and numerical variables as mean ( \pm standard deviation) and median values. For the comparison of two independent groups, numerical variables with normal distribution were analyzed using Student's t-test, while the Mann-Whitney $U$ test was used for those with non-normal distribution. For the comparisons of dependent groups, mean differences of variables fitted to normal distribution were analyzed with paired-samples t-test, while the Wilcoxon-signed rank test was used for those without normal distribution. A p value of less than 0.05 was considered statistically significant.

\section{Results}

There was no statistically significant difference in mean irisin and visfatin levels at postprocedural $2^{\text {nd }}$ and $4^{\text {th }}$ hours between rats with TT and controls $(p=0.559$, $p=0.125, p=0.631$, and $p=0.435$, respectively). A statistically significant change was not detected between the TT and control groups as for postprocedural mean $4^{\text {th }}$ and $2^{\text {nd }}$ hour measurements ( $p=0.735, p=0.939, p=0.398$, and $p=0.555$, respectively). Mean differences in irisine and visfatin levels were not statistically significant between the groups ( $p=0.655$ and $p=0.611$, respectively) (Table 1 ).

\section{Histopathology}

Distribution of the stages of testicular injury induced in rats was as follows:

\begin{tabular}{|c|c|c|c|c|c|}
\hline & \multicolumn{2}{|l|}{ Control } & \multicolumn{3}{|l|}{ Torsion } \\
\hline & Mean & Median & Mean & Median & $p$ \\
\hline İrisine 2.hr & $3.15 \pm 0.69$ & 3.27 & $2.97 \pm 0.38$ & 2.96 & 0.559 \\
\hline İrisine 4.hr & $3.44 \pm 0.90$ & 3.07 & $2.76 \pm 0.44$ & 2.82 & 0.125 \\
\hline$p$ & \multicolumn{2}{|l|}{0.735} & \multicolumn{2}{|l|}{0.398} & - \\
\hline $\begin{array}{l}\text { Difference } \\
\text { in irisine } \\
\text { levels }\end{array}$ & $-0.28 \pm 1.35$ & 0.45 & $0.21 \pm 0.65$ & 0.17 & 0,655 \\
\hline $\begin{array}{l}\text { Visfatin } \\
\text { 2.hr }\end{array}$ & $251.0 \pm 33.2$ & 247.3 & $261.0 \pm 41.8$ & 255.7 & 0.631 \\
\hline $\begin{array}{l}\text { Visfatin } \\
\text { 4.hr }\end{array}$ & $253.0 \pm 66.9$ & 241 & $292.2 \pm 109.6$ & 273.7 & 0.435 \\
\hline$p$ & \multicolumn{2}{|l|}{0.939} & \multicolumn{2}{|l|}{0.555} & - \\
\hline $\begin{array}{l}\text { Difference } \\
\text { in visfatin } \\
\text { levels }\end{array}$ & $-2.0 \pm 66.7$ & 19.7 & $-31.2 \pm 132.3$ & -22.1 & 0.611 \\
\hline Hr: Hour & & & & & \\
\hline
\end{tabular}

Stage 1 (group 1: $n=7$ and group 2: $n=6$ ), stage 2 (group 2: $n=1$, group 3: $n=4$ and group $4: n=1$ ), stage 3 (Group 3: $n=1$ and group 4: $n=1$ ), stage 4 (Group 3: $n=2$, group 4: $n=5$ ) (Figure 1).

A statistically significant difference was found between control and torsion groups as for mean, and median levels of irisin and visfatin measured at 2 . and 4 . hours following $\mathrm{TT}(p=0.001)$. A statistically significant difference was not detected between postprocedural $2^{\text {nd }}$ and 4 th hour measurements in the control and torsion groups.

\section{Discussion}

$\mathrm{TT}$ is the most frequently seen cause of scrotal emergencies in young men aged $<25$ years with an incidence of 1/4000 and it requires emergency treatment. It is the most frequent cause of testicular loss in adolescents. It is defined as cessation of blood flow into the testis, and its appendages caused by rotation of the spermatic cord around its axis (1-6). Based on the severity of ischemia and reperfusion injury, testicular damage occurs. Free oxygen radicals (FORs), which are released as a result of ischemia, and subsequent reperfusion are responsible for the development of testicular damage. FORs lead to lipid peroxidation in cell membranes with resultant denaturation of proteins and cell damage $(2,18)$. $\mathrm{TT}$ is an important diagnosis because of the risk of infarct, and infertility. Abnormalities in the semen parameters in more than $35 \%$ of patients and development of infertility in nearly $25 \%$ of patients have been reported. Production of FORs and antisperm antibodies, neutrophil infiltration and decrease in the blood flow into contralateral testis lead to development of destructive changes in both testes (2-6).

Recovery of the testis depends on the degree and duration of the torsion. It has been demonstrated that TT of $360^{\circ}$ does not adversely affect fertility while testicular rotations of $\geq 720^{\circ}$ exert harmful effects on the testes. In our study on rats, we induced a TT of $720^{\circ}$. If the rotated testis is intervened within the first six hours after torsion,

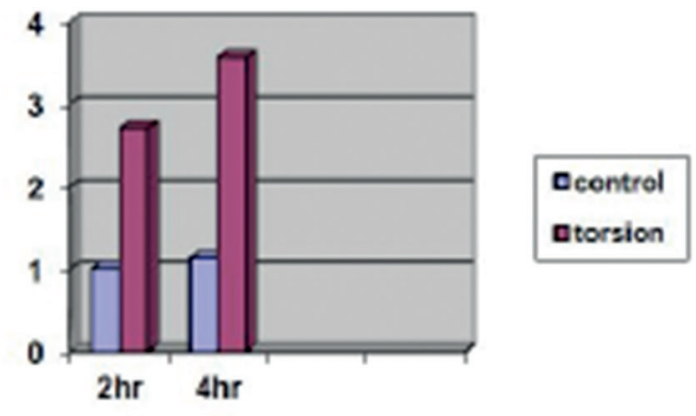

Figure 1. Distribution of testicular injury according to diase stages Hr: Hour 
recovery is highly probable. Testicular viability decreases dramatically 12 hours after torsion. Rates of testicular recovery following detorsion within six, 12 and 24 hours have been reported to be $90 \%, 50 \%$ and less than $10 \%$, respectively (6).

TT is the most important cause of acute scrotum. In the differential diagnosis epididymitis, orchitis, torsion of testicular appendix, hydrocele, epididymal cyst, abscess, spermatocel, urolithiasis, cancer, and trauma should be considered. Its symptoms include testicular pain of sudden onset, scrotal swelling, rash and sometimes concomitant lower abdominal quadrant pain, nausea and vomiting. Physical examination carries utmost importance. Twisted testis is tender and lies at a higher level relative to the contralateral testis. Scrotal edema and erythema aggravate in parallel with increased severity of ischemia (3-5).

Since waste of time for the establishment of diagnosis will lead to testicular loss, diagnostic process should be completed as fast as possible. Doppler US is the firstly preferred diagnostic method $(1,3,4)$. Though color Doppler US is a reliable test in the diagnosis of TT, falsenegative results can be seen. Kalfa et al. (19) described the advantages of high-resolution US (HRUS) which enables direct visualization of the rotation of spermatic cord. In a study performed on 919 patients, the sensitivity of color Doppler US was determined as 76\%, while sensitivity and specificity of HRUS were $96 \%$ and $99 \%$, respectively (3). Testicular scintigraphy is another diagnostic modality $(3,4)$. However, in these patients admitted to the emergency department, it is not always possible to use these necessary diagnostic methods. In patients with TT, limited number of specific and sensitive serum parametres can be used for early diagnosis and, therefore, further studies on new biomarkers should be conducted.

In a study performed by Turedi et al. (18), an increase in the plasma levels of SCUBE 1 , which is a new and effective indicator of platelet activation, has been demonstrated in cases with TT.

In a study by Güneş et al. (5), the authors investigated the roles of neutrophil/lymphocyte ratio, platelet/ lymphocyte ratio, mean platelet volume, and platelet counts in the diagnosis of TT, and in the demonstration of testicular viability after the torsion, and reported neutrophil/lymphocyte ratio as a beneficial parameter in the diagnosis, and the prognosis of TT.

In our study we measured serum irisin, and visfatin levels in the rats two and four hours after induction of TT.

Irisin is recognized as an exercise-induced hormone derived from skeletal muscle. It was firstly defined by Boström et al. (7) as glycosylated polypeptide which originates from skeletal muscle $(9,14)$. FNDC5 is a protein which induces secretion of irisin hormone from muscle cells $(9,13)$. Immunohistochemical studies revealed that it was synthetized in abundant amounts in myocardium and connective tissue of the heart muscle. Besides, immunoreactivity of irisin has been detected in the salivary glands, kidneys, ovary, testes, rectum, intracranial arteries, and stomach, etc. $(8,10-12)$. FNDC5 mRNA which is the precursor of irisin is secreted from the seminal vesicles, penis, and testes $(11,14)$.

As determined in various studies, serum irisin levels decrease in type 2 diabetes mellitus (DM) and gestational DM, non-alcoholic hepatic failure and in individuals with lower body mass indices vs. obese individuals and increase in metabolic syndrome (14,20-23).

Visfatin was firstly defined by Samal et al. (24) as a growth hormone for $\beta$-lympocyte precursors. Basically, it is an adipokine synthetized by visceral white adipose tissue (25). It has been determined that visfatin increases the effects of interleukin (IL)-7 and stem cell factor on $\beta$-cells and, thus, named as pre-B-cell colony-enhancing factor (PBEF). This protein also has the enzymatic activity of nicotinamide phosphoribosyltransferase (Nampt) which is critically important for the synthesis of the cofactor nicotinamide adenine dinucleotide required for cell metabolism. Visfatin, PBEF and Nampt are used to define the same protein $(16,24,26)$.

The main source of plasma visfatin has been found to be leucocytes (especially granulocytes) (16). As demonstrated in many studies, visfatin has proinflammatory effects and increases synthesis of IL-1 b, tumor necrosis factor-alpha and IL-6 in a dose-dependent manner. Besides, it increases expression of some anti-inflammatory cytokines including IL-10 and IL-1 Ra and also of CD54, CD40 and CD80 which are important co-stimulator molecules significant for T-cell activation effective on the surface of monocytes $(15,16,25)$. Increased visfatin levels have been indicated in models of acute pulmonary injury, experimental inflammation and clinical sepsis. Higher visfatin levels were found in neutrophils of patients with sepsis. Besides, increased serum visfatin levels were detected in inflammatory bowel disease. Moreover, in studies performed on rats, the role of visfatin on the activation of NF- $\kappa B$, which has an important place in the induction and regulation of immune response, has been reported. All these outcomes demonstrate the involvement of visfatin in the inflammatory process (25).

In our study in rats with experimentally induced TT, serum irisin and visfatin levels at the $2^{\text {nd }}$ and $4^{\text {th }}$ hours were compared with those in controls without any statistically significant intergroup difference. Besides, any statistically significant difference was not detected between mean serum irisin, and visfatin levels of the torsion, and the control groups as estimated at postprocedural two and four hours. Histopathological examination results of the 
testicular tissue specimens harvested at the $2^{\text {nd }}$ and $4^{\text {th }}$ hours in the torsion and the control groups were statistically significantly different.

TT is an important pathology in young male population which can lead to testicular loss and infertility. Studies are being conducted concerning its etiology, rapid diagnosis, medical and surgical treatment. In this experimental study of ours, we investigated serum levels of irisin and visfatin in TT-induced rats without any statistically significant difference in our outcomes relative to other studies. We have concluded that irisin and visfatin have not any diagnostic value. We assume that further studies on irisin and visfatin should be performed.

This study has some limitations. Since TT is most frequently seen in young adults, we preferred to use prepubertal rats in this experimental study. Hemodynamic characteristics of prepubertal rats pose some differences when compared with adult rats, and human beings. Besides, experimental model may not exactly mimic typical cases of TT seen in daily clinical practice. Though in patients with TT post-detorsion reperfusion injury is a very well recognized important factor as ischemia in testicular recovery, in this experimental model, detorsion was not applied. Besides, groups of rats exposed to longer periods of torsion could be included in the study.

\section{Conclusion}

In this experimental study, we concluded that biomarkers of irisin, and visfatin do not aid in the diagnosis of TT. We think that more comprehensive studies should be conducted to confirm this assertion.

\section{Ethics}

Ethics Committee Approval: Our experimental study was performed in Experimental Animal Studies Research Laboratory of Bezmialem Foundation University (number of ethics approval: 2015/132).

Peer-review: Externally peer-reviewed.

\section{Authorship Contributions}

Surgical and Medical Practices: F.S., S.Y. Concept: F.S., S.Y., S.B.S. Design: F.S., S.Y., S.B.S. Data Collection or Processing: F.S., S.Y., M.T., E.Y., V.O., M.K. Analysis or Interpretation: F.S., S.Y., M.T., E.Y., M.K. Literature Search: F.S., S.Y., S.B.S., M.T., V.O. Writing: F.S., S.Y.

Conflict of Interest: The authors declare that they have no conflicts of interest.

Financial Disclosure: Financial support for the study was received from Advisory, and Monitoring Commission for Dissertations, and Academic Studies of Haseki Training and Research Hospital (Project number: 14.01.2015/30).

\section{References}

1. Rashed FK, Ghasemi B, Deldade Mogaddam H, Mesgari M. The effect of erythropoietin on ischemia/reperfusion injury after testicular torsion/detorsion: a randomized experimental study. ISRN Urol 2013;2013:351309.

2. Cvetkovic T, Stankovic J, Najman S, et al. Oxidant and antioxidant status in experimental rat testis after testicular torsion/detorsion. In J Fertil Steril 2015;9:121-8.

3. DaJusta DG, Granberg CF, Villanueva C, Baker LA. Contemporary review of testicular torsion: new concepts, emerging technologies and potential therapeutics. J Pediatr Urol 2013;9:723-30.

4. Matthews PN. Spermatic cord torsion. Arch Dis Child 1986;62:426-7.

5. Güneş $M$, Umul $M$, Altok $M$, et al. Predictive role of hematologic parameters in testicular torsion. Korean J Urol 2015;56:324-9.

6. Reyes JG, Farias JG, Henriquez-Olavarrieta S, et al. The hypoxic testicle: physiology and pathophysiology. Oxid Med Cell Longev 2012;2012:929285.

7. Boström PA, Fernandez-Real JM, Mantrozos C. Irisin in humans: recent advances and questions for future research. Metabolism 2014;63:178-80.

8. Aydin S, Kuloglu T, Aydin S, et al. A comprehensive immunohistochemical examination of the distribution of the fat-burning protein irisin in biological tissues. Peptides 2014;61:130-6.

9. Polyzos SA, Kountouras J, Shields K, Mantzoros CS. Irisin: a renaissance in metabolism. Metabolism 2013;62:1037-44.

10. Huh JY, Panagiotou G, Mougios $V$, et al. FNDC5 and irisin in humans: I. Predictors of circulating concentrations in serum and plasma and II. mRNA expression and circulating concentrations in response to weight loss and exercise. Metabolism 2012;61:1725-38.

11. Kuloglu T, Aydin S, Eren MN, et al. Irisin: a potentially candidate marker for myocardial infaction. Peptides 2014;55:85-91.

12. Roca-Rivada A, Castelao C, Senin LL, et al. FNDC5/irisin is not only a myokine but also an adipokine. PLoS One 2013;8:60563.

13. Spiegelman BM. Banting lecture 2012: Regulation of adipogenesis: toward new therapeutics for metabolic disease. Diabetes 2013;62:1774-82.

14. Chen JQ, Huang YY, Gusdon AM, Qu S. Irisin: a new molecular marker and target in metabolic disorder. Lipids Health Dis 2015;14:2.

15. Sommer G, Garten A, Petzold S, et al. Visfatin/ PBEF/ Nampt: structure, regulation and potential function of a novel adipokine. Clin Sci (Lond) 2008;115:13-23.

16. Friebe $D$, Neef $M$, Kratzsch J, et al. Leucocytes are a major source of circulating nicotinamide phosphoribosyltransferase (NAMPT)/pre-B cell colony (PBEF)/visfatin linking obesity and inflammation in humans. Diabetologia 2011;54:1200-11.

17. Cosentino MJ, Nishida M, Rabinowitz $R$, Cockett AT. Histopathology of prepubertal rat testes subjected to various durations of spermatic cord torsion. J Androl 1986;7:23-31. 
18. Turedi S, Tatli O, Alver A, et al. The Diagnostic Value of Plasma SCUBE 1, a Novel Biomarker of Platelet Activation, in testicular Torsion: A Randomized, Controlled, Experimental Study. Urology 2015;86:516-20.

19. Kalfa N, Veyrac C, Lopez M, et al. Multicenter assesment of ultrasound of the spermatic cord in children with acute scrotum. J Urol 2007; 177:297-301.

20. Liu JJ, Liu S, Wong MD, et al. Relationship between circulating irisin, renal function and body composition in type 2 diabetes. J Diabetes Complications 2014;28:208-13.

21. Liu JJ, Wong MD, Toy WC, et al. Lower circulating irisin is associated with type 2 diabetes mellitus. J Diabetes Complications 2013;27:365-9.

22. Piya MK, Harte AL, Sivakumar $K$, et al. The Identification of irisin in human cerebrospinal fluid: influence of adiposity, metabolic markers, and gestational diabetes. Am J Physiol Endocrinol Metab 2014;306:512-8.
23. Park KH, Zaichenko $L$, Brinkoetter $M$, et al. Circulating irisin in relation to insulin resistance and the metabolic syndrome. J Clin Endocrinol Metab 2013;98:4899-907.

24. Samal B, Sun Y, Stearns G, Xie C, Suggs S, McNiece I. Cloning and charecterization of the cDNA encoding a novel human pre-B-cell colony-enhancing factor. Mol Cell Biol 1994;14:1431-7.

25. Moschen AR, Kaser A, Enrich B, et al. Visfatin, an adipocytokine with proinflammatory and immunomodulating properties. J Immunol 2007;178:1748-58.

26. Jacgues C, Holzenberger $M$, Mladenovic $Z$, et al. Proinflammatory actions of visfatin/nicotinamide phosphoribosyltransferase (Nampt) involve regulation of insulin signaling pathway and Nampt enzymatic activity. J Biol Chem 2012;287:15100-8. 